\begin{tabular}{|c|c|}
\hline 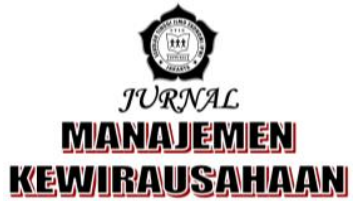 & $\begin{array}{r}\text { p-ISSN 1858-1048 } \\
\text { e-ISSN 2654-9247 } \\
\text { http://ejurnal.stieipwija.ac.id/index.php/jmk } \\
\text { DOI: } \text { http://dx.doi.org/10.33370/jmk.v16i2.346 } \\
\text { Jurnal Manajemen Kewirausahaan Vol. 16 No. 02 - Desember 2019 } \\
\text { Submit: } 30 \text { Nov 2019; Review: 05 Des 2019; Publish: 30 Des } 2019\end{array}$ \\
\hline
\end{tabular}

\title{
PENGARUH BAURAN PEMASARAN TERHADAP KEPUASAN DAN KEPERCAYAAN SERTA DAMPAKNYA PADA LOYALITAS KONSUMEN
}

\author{
Oleh: \\ Aep Nurbani'1); Heru Mulyanto2); Mursida Kusuma Wardani ${ }^{3)}$ Meli Andriyani ${ }^{4}$ ) \\ aepnurbanimm@gmail.com ${ }^{1)}$; drherumulyanto@gmail.com ${ }^{2)}$; idha_mkw@yahoo.com ${ }^{3)}$; \\ my_odah@yahoo.com ${ }^{4}$ \\ Harvest City1); Sekolah Tinggi Ilmu Ekonomi IPWI Jakarta2,3,4)
}

\begin{abstract}
ABSTRAK
Marketing mix and customer satisfaction are two of the factors that are though to be relatively large in influencing trust and have a large impact on loyalty. As one way to find out the inluential variables, this research is conducted, which is to find out the impact of loyalty from the inflence of the marketing mix, satisfaction and trust.

The 100 samples used in thi study are the people in Harvest City Housing. In this case the use of explanatory research is causal type explanatory research that seeks to test the influence of variables in a structural model. The study was conducted by testing one exogenous variable and three endogenous variables.

The reseach resulted in the inding of the model analysis results are feasible due to the influence of marketing mix, satisfaction and trust and their impact on consumer loyalty in the equation model $0.805 \mathrm{MM}+1-0.83 \mathrm{R} 2=0.17,0.440 \mathrm{MM}+0.364 \mathrm{SC}+$ error $0.89 R 20.11$ and $0.137 \mathrm{MM}+0.223 \mathrm{SC}+0.519 \mathrm{TR}+$ error $0.82 \mathrm{R} 20.18$ where: 1) The marketing mix has no effect on loyalty. 2) Marketing mix influence trust. 3) The marketing mix has no effect on loyalty. 4) Satisfaction does not affect trust. 5) Satisfaction does not affect loyalty. 6). Trust influence loyalty.

Based on these findings, it is suggested to improve loyalty to improve the quality of the marketing mix, customer satisfaction and trust.
\end{abstract}

Keyword: Marketing Mix, Satisfaction, Trust and Loyalty

\section{PENDAHULUAN}

Semakin banyaknya jumlah penduduk di Indonesia maka semakin banyak pula orang yang membutuhkan tempat tinggal. Maka menjadi perhatian khusus bagi para pengembang di bidang property untuk mengembangkan sayap pemasarannya di bidang property terutama perumahan. Hal ini merupakan potensi yang sangat besar dimana kebutuhan utama bagi masyarakat adalah kebutuhan akan makan, pakaian dan tempat tinggal. Kebutuhan akan tempat tinggal menjadi hal yang penting bagi masyarakat dimana mereka dapat hidup dengan layak dalam sebuah perumahan. Jika melihat semakin banyaknya jumlah penduduk di suatu wilayah yang notabene merupakan wilayah padat penduduk, maka mau tidak mau masyarakat akan mencari tempat tinggal ataupun perumahan di wilayah yang lebih baik. Sebagai contoh adalah kota Jakarta, dimana wilayah ini merupakan wilayah kota yang merupakan tempat bisnis yang memiliki 
ruang terbatas bagi tempat tinggal untuk masyarakat. Jika ingin memiliki rumah di Jakarta maka masyarakat harus memiliki nilai uang yang lebih. Oleh karena itu mau tidak mau mereka harus mencari perumahan yang berada di sekitar wilayah Jakarta.

Disinilah tugas para pengembangan perumahan untuk menjaring konsumen yang ingin memiliki tempat tinggal atau rumah dengan berbagai macam cara dalam memasarkan perumahan tersebut. Biasanya setiap konsumen memiliki pandangan yang berbeda ataupun persepsi dalam melakukan keputusan mencari tempat tinggal. Bagaimanapun masyarakat akan mengupayakan pencarian tersebut dengan mempertimbangan unsur-unsur yang meliputi aktifitas mereka.

Unsur dalam konsumen memilih tempat tinggal antara lain meliputi bauran pemasaran yang berupa produk atau perumahan yang ditawarkan, harga dan tempat maupun lokasi serta bagaimana konsumen mendapatkan kemudahan dalam memperoleh informasi yaitu mengenai promosi produk perumahan yang mereka dapat akses. Konsumen juga dapat memilih tempat tinggal berdasarkan pada motivasi dimana kualitas produk menjadikan salah satu indikator dalam konsumen memilih.

Konsumen akan merasa puas manakala kebutuhan dan keinginan yang diikuti kemampuan daya beli dapat mereka capai seiring dengan adanya nilai serta manfaat dari produk yang mereka inginkan. Jika kepuasan konsumen dapat dicapai maka secara alamiah merekapun akan menumbuhkan rasa percaya pada produk tersebut. Kepercayaan tidak bisa datang begitu saja, apalagi di dunia property dengan saingan yang begitu banyak kompleksitas harga yang tinggi, maka para pengusaha properti sebagai pengembang harus lebih memberikan konsumen kepercayaan, baik berupa pelayanan, komunikasi yang baik atau peningkatan mutu produk sesuai dengan yang diharapkan oleh konsumen serta bauran pemasaran (produk, place, price dan promotion) menjadi penopang tertinggi meningkatkan kepercayaan konsumen terhadap developer, Putra (2016). Kepuasan konsumen itu akan terjadi ketika bauran pemasaran baik dari produk, tempat, harga dan promosi yang ditawarkan oleh developer sesuai dengan harapan dan ekspektasinya pada saat pembelian unit rumah (Norhermaya dan Soesanto, 2009).

Oleh karena itu daya saing ditingkat usaha property sangat mempengaruhi keberlangsungannya dalam mendapatkan kepercayaan konsumen serta berapa besar masyarakat menjadi loyal terhadap pengembangan perumahan tersebut. Konsumen yang mendapatkan produk maupun jasa yang sesuai dengan harapannya pada akhirnya akan menjadi konsumen yang meiliki tingkat loyalitas. Hal ini tidak mudah untuk dilakukan oleh perusahaan property karena menyangkut semua aspek yang harus dilakukan. Harvest City sebagai salah satu pengembang yang sudah berpengalaman dibidang property tentu saja mempunyai strategi untuk mencapai tujuan tersebut (Qurroty, 2012).

Kepercayaan konsumen mengenai produk atau jasa berlandaskan pada berbagai hal diantaranya kepuasan tentang bauran pemasaran. Dimana hal tersebut membuat konsumen melakukan kegiatan promosi secara tidak langsung kepada keluarga, rekan kerja, teman dan lain sebagainya. Merujuk pada Mursida Kusuma Wardani dan David Fajri (2016) salah satu faktor yang mempengaruhi adanya loyalitas konsumen yaitu tentang kepuasan konsumen. Selain itu juga Kepuasan Konsumen akan dipengaruhi oleh Produk, Harga, Tempat, dan Promosi (Cory Caroline R.M, Edy Yulianto dan Sunarti, 2016).

Kepuasan adalah rasa yang digambarkan oleh seseorang tentang sesuatu. Gambaran itu meliputi perasaan tentang kesenangan, kebahagiaan serta kekecewaaan atas produk yang diharapkan. Karena apabila harapan konsumen tidak terpenui maka mereka akan kecewa dan tidak puas. Rasa tidak puas ini manakala ekspektasi yang mereka harapkan tidak tercipta atau dengan kata lain dimana nilai dan 
manfaat akan produk atau jasa tidak dapat dicaai. Kepuasan konsumen telah menjadi konsep sentral dalam wacana bisnis dan manajemen. Konsumen umumnya mengarapkan produk yang berkualitas dan dapat dinikmati dengan pelayanan baik dan memuaskan. Kepuasan dapat membentuk persepsi dan hal ini dapat memposisikan produk perusahaan dimata konsumennya. Hal tersebut penting sebagai acuan dalam pembenahan kualitas pelayanan, sehingga pelayanan yang diberikan bisa memberikan kepuasan pada tingkat yang optimal (Satyadharma, 2008).

\section{TUJUAN PENELITIAN}

Tujuan yang hendak dicapai bagi penelitian ini adalah mengetahui dampak loyalitas konsumen diperumahan Harvest City dari pengaruh variabel bauran pemasaran, kepuasan dan kepercayaan.

\section{TELAAH LITERATUR DAN PENGEMBANGAN HIPOTESIS Manajemen Pemasaran}

Unsur kegiatan pemasaran merupakan aktifitas di perusahaan maupun instansi/institusi untuk meningkatkan usaha serta menjaga keberlangsungan operasional perusahaan dan perkembangan dari usaha tersebut. Selain aktifitas pemasaran perusahaan senantiasa dapat melakukan kombinasi fungsi manajemen dan mendayagunakan keahlian yang dimiliki untuk keberlangsungan perusahaan sehingga berjalan dengan baik sesuai yang telah direncanakan serta mencapai tujuan yang diingikan.

Merujuk pada Lupiyoadi (2006:6) antara lain: manajemen pemasaran merupakan aktifitas menganalisis perencanaan, pelaksanaan dan mengontrol program yang berhubungan dengan pertukaran yang diinginkan oleh konsumen tujuan untuk keuntungan secara individu atau kebersamaan.

\section{Kepuasan Konsumen}

Pentingnya kepuasan konsumen berkaitan dengan persaingan yang makin ketat, serta tingkat kerugian dan keuntungan perusahaan. Khusus alas an yang terakhir, keuntungan memang tidak selalu ditentukan oleh factor kepuasan, tetapi juga oleh adanya rasa percaya juga tingkat kesetiaan konsumen atas suatu produk maupun perusahaan. Beberapa faktor itu jelas saling mempengaruhi karena ditengah ketatnya persaingan, kesetiaan konsumen menjadi hal yang sangat sulit dipertahankan.

Kepuasan konsumen menurut Husein Umar (2003:50) adalah tingkat perasaan konsumen setelah membandingkan dengan harapannya. Seorang konsumenjika merasa puas dengan nilai yang diberikan oleh produk atau jasa maka sangat besar kemungkinannya untuk menjadi konsumendalam waktu yang lama.

Kotler (2009:69) mengatakan bahwa kepuasan konsumen merupakan tingkat perasaan seseorang telah membandingkan antara kinerja produk yang ia rasakan dengan harapannya.

Westbrook \& Reily (dalam Tjiptono, 2008:23) mengemukakan bahwa kepuasan konsumen merupakan respon emosional terhadap pengalaman yang berkaitan dengan produk atau jasa yang dibeli.

Zeitahmi dan Bitner (2003:93) mengemukakan bahwa kepuasan konsumen dipengaruhi oleh beberapa faktor meliputi:

a. Kualitas pelayanan

Tiga hal yang menjadi ketergantungan mutu pelayanan yaitu sistem, teknologi dan manusia. Perusahaan yang bergerak dibidang jasa sangat bergantung pada kualitas produk yang diberikan. Kualitas pelayanan memiliki lima dimensi yaitu, keandalan (reliability), responsif (responsiveness), keyakinan (assurance), berwujud (tangibles), dan empati (empathy).

b. Kualitas produk

Konsumen puas jika setelah membeli dan menggunakan produk, ternyata kualitas produknya baik. Kualitas barang yang diberikan bersamasama dengan pelayanan akan mempengaruhi persepsi konsumen. 
Ada delapan elemen dari kualitas produk yakni, kinerja, fitur, reliabilitas, daya tahan, pelayanan, estetika, sesuai dengan spesifikasi dan kualitas penerimaan.

c. Harga

Pembeli biasanya memandang harga sebagai indicator dari kualitas suatu produk. Konsumen cenderung menggunakan harga sebagai dasar menduga kualitas produk. Maka konsumen cenderung berasumsi bahwa harga yang lebih tinggi mewakili kualitas yang lebih tinggi.

d. Faktor situasi dan personal

Keadaan ekonomi secara individu baik lingkungan pribadi dan masyarakat memberikan dampak atas kepuasan tentang barang atau jasa yang digunakan. Nilai serta manfaat suatu barang maupu jasa yang dipakai oleh konsumen dapat membuat mereka datang lagi ke tempat dimana mereka mendapatkan hal tersebut yang baginya adalah merupakan pengalaman an tentu saja secara emosional mempengaruhi tindakan konsumen.

\section{Kepercayaan Konsumen}

Bagaimana konsumen mendapat kepercayaan apabila mereka tidak memahami arti dari adanya produk atau jasa yang dipakai. Orang percaya apabila telah melakukan rangkaian dalam proses aktifitas pemasaran seperti membeli, mencoba, merasakan dan lainnya atas nilai maupun manfaat dari sebuah produk ataupun jasa. Kepercayaan konsumen itu dapat berbeda-beda berdasarkan padahal yang mereka inginkan serta daya beli dari suatu produk atau jasa yang ditawarkan oleh perusahaan.

Rasa percaya yang timbul dalam diri konsumen juga merupakan tanggung jawab perusahan institusi maupun instansi dalam mengkomunikasikan atribut suatu produk/jasa kepada konsumen. Menurut Sumarwan (2003: 136), bahwa kepercayaan konsumen merupakan persepsi yang timbul dari konsumen atas produk, atribut serta manfaat yang mereka dapatkan dari produk. Sehingga konsumen akan memiliki kepercayaan yang berbedabeda.

Mowen dan Minor (2002:312) menjelaskan bahwa Kepercayaan konsumen (consumer trust), adalah Kesimpulan yang dibuat oleh konsumen berdasarkan pada pengetahuan yang dimiliki tentang objek, atribut serta manfaat yang ada didalamnya sehingga mareka dapat meyikapi dan percaya tentang hal tersebut.

Menurut Sumarwan (2003:151) bahwa kepercayaan akan suatu produk karena atribut tertentu yang dimiliki dan bagaimana konsumen mengevaluasi terhadap atribut suatu merek. Konsumen dapat melihat dengan seksama atas produk yang dibeli sehingga dapat melakukan evaluasi atribut dari setiap merek. Oleh karena itu Kepercayaan dapat diasumsikan sebagai rangkaian yang berhubungan antara atribut yang dimiliki oleh merek sehubungan dengan nilai dan manfaat yang dihadirkan oleh produk.

Maka menjadi perhatian khusus bagi perusahaan dalam memberikan rasa kepercayaan kepada konsumen atas produk atau jasa yang dihasilkan, karena konsumen memiliki tingkat kepercayaan yang berbeda-beda atas objek, atribut serta manfaat yang didapatkan dalam setiap merek yang diproduksi.

\section{Loyalitas Konsumen}

Salah satu cara untuk mencapai keunggulan dan peningkatan laba yang berkelanjutan adalah melalui loyalitas pelanggan. Konsumen property akan melakukan pembelian yang berulang kali serta bersedia member rekomendasinya kepada temannya, keluarganya dan lainnya. Menurut Gaffar (2007), menyatakan bahwa loyalitas adalah apabila seseorang merasa setia dalam jangka waktu tertentu terhadap produk dimana mereka juga senantiasa melakukan pembelian secara teratur dan pelaksanaan pembelian tidak secara acak mereka gunakan. Tumbuhnya loyalitas konsumen menjadi tolak ukur bagi perusahaan dalam penilaian kinerja atas meningkatnya kinerja keuangan serta keberlangsungan operasional 
perusahaan. Sehingga harus melakukan upaya peningkatan dalam mempertahankan pelanggan dan menumbuhkan pelanggan baru.

Oliver dalam Hurriyati (2005:129) mendefinisikan loyalitas konsumen adalah bagaimana konsumen bertahan untuk berlangganan dan secara terus menerus melakukan pembelian secara ulang tanpa dipengaruhi kondisi pemasaran yang menyebabkan potensi perubahan bagi konsumen.

Ikatan emosional inilah yang membuat konsumen menjadi loyal dan mendorong mereka untuk terus melakukan pembelian terhadap produk perusahaan serta memberikan rekomendasi. Untuk meningkatkan loyalitas, perusahaan harus meningkatkan kepuasan setiap konsumendan mempertahankan tingkat kepuasan tersebut dalam jangka panjang. Untuk meningkatkan kepuasan, perusahaan haus menambah nilai yang dapat membuat mereka mendapatkan apa yang mereka bayar atau lebih dari mereka harapkan, sehingga mereka dapat bertahan dan mengarah pada pembelian ulang, perekomendasian, dan proporsi pembelanjaan yang meningkat.

Tingkat loyalitas konsumen merupakan kesetiaan sesorang akan penggunaan produk atau jasa tertentu. Loyalitas konsumen adalah salah satu indikator keberlanjutan dari kepuasan konsumen atas atribut dan nilai maupun manfaat yang diharapkan dan sesuai dengan ekspektasi. Loyalitas merupakan salah satu bukti bagi perusahan dari konsumen berupa keberlanjutan konsumen untuk terus melakukan pembelian produk maupun penggunaan jasa yang diinginkan. Pentingnya loyalitas konsumen merupakan kunci bagi perusahaan dalam memperhitungkan berapa pelanggan yang terus bertahan, konsumen yang datang serta berapa konsumen yang hilang. Ini sebagai tolak ukur dalam menghitung kinerja perusahaan yaitu kinerja keuangan serta operasionalisasi keberlangsungan perusahaan. Alasan utama perusahaan dalam mempertahankan konsumen adalah biaya yang mahal yang harus dikeluarkan perusahaan untuk mencari konsumen baru serta tingkat kemampuan laba perusahaan yang berbanding lurus dengan pertumbuhan hubungan antara perusahaan serta konsumen yang secara permanen.

Loyal dapat diartikan bahwa tingkat kesetianan seseorang terhadap produk maupun jasa tanpa adanya unsur keterpaksaan namun timbul karena adanya motivasi atau dorongan dari dalam individu itu sendiri. Ada beberapa tokoh yang mengemukakan definisi loyalitas. Menurut Oliver yang dikutip Hurriyati (2005:128), loyalitas konsumen merupakan ketetapan seseorang dalam bertahan menjadi pelanggan serta senantiasa melakukan pembelian ulang atas produk atau jasa yang diinginkan secara terus menerus dari masa ke masa walaupun sistem pemasaran dapat merubah potensi perilaku seseorang dalam bertindak. Sementara itu merujuk pada Griffin (2002;4), dimana loyalitas didefinisikan sebagai pembelian ekpres non acak dari waktu ke waktuoleh beberapa unit pengambil keputusan. Loyalitas konsumen mengacu kepada perwujudan para pengambil keputusan yang melakukan pembelian secara kontinu terhadap barang atau jasa perusahaan institusi maupun instansi yang telah dipilih.

Sedangkan menurut Lovelock (2004:352), loyalitas menggambarkan kediaan pelanggan untuk terus setia pada perusahaan akan produk atau jasa secara terus menerus serta merekomendasikan kepada teman atau rekan bisni. Loyalitas konsumen berasal dari penilain konsumen kepada kualitas barang atau jasa yang mereka pilih dan sesuai dengan ekspektasinya. Ekspektasi yang terbentuk bisa berasal dari pengalaman atas produk atau jasa yang digunakan atau juga atas informasi orang lain. Dimana nilai dan manfaat yang diharapkan dari suatu produk atau jasa memberikan nilai harapan. Apabila ekspektasi dari pelanggan tidak terpenuhi maka akan terjadi kekecewaan yaitu berupa rasa tidak puas dan sebaliknya maka konsumen tidak puas. 
Loyalitas seseorang ditunjukan dengan aktifitas konsumen yang tanpa keterpaksaan serta tanpa adanya tekanan dari pihak manapun dalam melakukan pilihan atas produk atau jasa yang diinginkan. Munculnya sikap loyal pada seseorang atas perusahaan, institusi maupun instansi merupakan tujuan akhir yang hendak dicapai dalam operasionalisasi perusahaan. Dimana perusahaan dapat menjadikan konsumen sebagai aset dalam menjalankan roda perusahaan serta pengembangan perusahaan.

Berdasarkan landasan teoritis dari penerapan diatas, maka kerangka pemikiran digambarkan dalam model penelitian sebagai berikut :

Gambar 1

Kerangka pemikiran

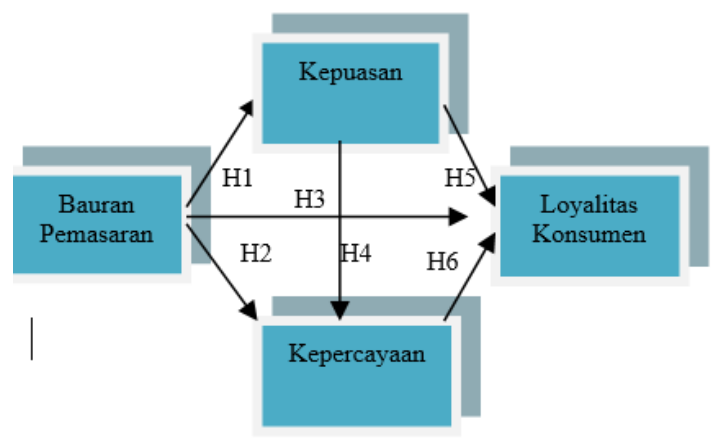

\section{METODE PENELITIAN \\ Sampel Penelitian}

Penelitian dilakukan di Perumahan Harvest City yang beralamatkan di jalan J1. Transyogi KM 15 Cibubur Cileungsi yaitu dengan mengambil sampel sejumlah 100 konsumen.

\section{Desain Penelitian}

Penelitian terdiri dari empat variabel yaitu variable eksogen marketing mix (MM) dan Satisfaction (SC) dan variabel endogen kategori intervening yaitu kepercayaan atau trust (TR) dan endogen kategori dependen yaitu loyality (LY). Variabel marketing mix diukur menggunakan 4 (empat) indikator (MM1, MM2, MM3, dan MM4). Variabel Satisfaction menggunakan 4 (empat) indikator (SC1, SC2, SC3 dan SC4).
Variabel trust menggunakan 3 (dua) indikator (TR1, TR2 dan TR3) sedangkan untuk loyality menggunakan 3 (tiga) indikator (LY1, LY2 dan LY3).

\section{Operasionalisasi Variabel}

Operasionalisasi variabel penelitian dapat dikemukakan sebagai berikut:

Tabel 1

Operasionalisasi Variabel

\begin{tabular}{|c|c|}
\hline Variabel & Indikator \\
\hline $\begin{array}{c}\text { Bauran Pemasaran } \\
\text { adalah seperangkat alat } \\
\text { pemasar yang digunakan } \\
\text { membentuk karakteristik } \\
\text { jasa yang ditawarkan } \\
\text { kepada pelanggan. } \\
\text { Nastiti (2007) }\end{array}$ & \begin{tabular}{|ll} 
1. & Product (MM1) \\
2. & Place (MM2) \\
3. & Price (MM3) \\
4. & Promotion (MM4) \\
& Tjiptono (2008:222)
\end{tabular} \\
\hline \begin{tabular}{|c|} 
Kepuasan konsumen \\
yaitu tingkat perasaan \\
seseorang setelah \\
membandingkan kinerja \\
produk yang dia rasakan \\
sesuai dengan \\
harapannya. Husein \\
Umar (2003:50)
\end{tabular} & 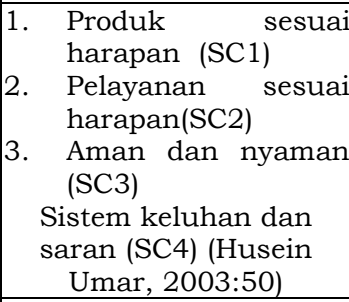 \\
\hline \begin{tabular}{|c|} 
Kepercayaan adalah \\
semua pengetahuan \\
yang dimiliki oleh \\
konsumen dan semua \\
kesimpulan yang dibuat \\
konsumen tentang objek, \\
atribut, dan manfaatnya \\
(Sunarto, 2009:153) \\
\end{tabular} & $\begin{array}{ll}\text { 1. } & \text { Integrity (TR1) } \\
\text { 2. } & \text { Benevolence (TR2) } \\
\text { 3. } & \text { Kompetency (TR3) } \\
\text { (Sumarwan, 2003:136) }\end{array}$ \\
\hline $\begin{array}{c}\text { Loyalitas adalah sebuah } \\
\text { usaha untuk tetap setia } \\
\text { dengan kesadaran, } \\
\text { kesan kualitas, } \\
\text { kepercayaan dan } \\
\text { kebangggan yang kuat } \\
\text { terhadap suatu produk } \\
\text { yang diikuti pembelian } \\
\text { ulang (Hadiyati, 2010). }\end{array}$ & \begin{tabular}{|ll} 
1. & Repeat Purcase \\
2. & (LY1) \\
2. & Refers Other (LY2) \\
3. & Recommendation \\
& (LY3) \\
& (Hadiyati, 2010)
\end{tabular} \\
\hline
\end{tabular}

\section{Metode Analisis}

Analisis data dilakukan dengan Model Persamaan Struktural yaitu Structural Equation Modelling atau SEM. SEM digunakan dalam penelitian ini mengingat SEM mampu mengukur faktor dan pengaruh antar variabel dalam model utuh secara serempak (bersamaan).

Pada penelitian ini analisis dilakukan dengan perangkat lunak AMOS (Analisis of Moment Structures) versi 20. Penelitian ini menggunakan pendekatan SEM yaitu pendekatan dua langkah (two-step approach) yaitu: 1) analisis dan pengujian terhadap model 
pengukuran untuk melihat hubungan yang ada di antara variabel laten; dan 2) analisis dan pengujian terhadap model struktural untuk melihat hubungan antara variabel laten dengan variabel pengukurnya. Langkah yang ditempuh dalam melakukan analisis menggunakan SEM pada penelitian ini adalah sebagai berikut (Hair, 1998):

1. Spesifikasi Model

Spesifikasi model pengukuran dilakukan dengan mendefinisikan variabel laten, indikator, dan hubungan keduanya. Spesifikasi model dilakukan dengan mendefinisikan hubungan kausal antar variabel laten. Hasil dari tahap spesifikasi adalah diagram lintasan (path diagram) yang merupakan model hybrid atau kombinasi antara model pengukuran dan model struktural.

2. Identifikasi

Dalam penelitian ini terdapat 4 variabel laten dan 14 indikator. Karena data sampel penelitian berjumlah 100 maka jumlah data telah memenuhi parameter yang diestimasi. Masing-masing variabel laten pada penelitian ini memiliki lebih dari dua variabel pengukur, maka untuk memberikan sebuah unit pengukuran dari setiap variabel laten digunakan Confirmatory Analysis (CFA).

\section{HASIL DAN PEMBAHASAN Hasil Penelitian}

Harvest City adalah sebuah kota mandiri terbesar di Cibubur dengan fasilitas lengkap dan lokasi strategis yang menyajikan hidup yang aman dan nyaman. Harvest City merupakan perumahan milik pengembang PT. Dwigunatama Rintisprima di Cileungsi. Perusahaan Property ini mengembangkan kawasan dari 1.050 menjadi 1.350 hektar dan juga akan mengembangkan jalan baru untuk arah Jonggol yang melintasi danau di wilayah Harvest City. Lahan ini lebih luas dibandingkan dengan perumahan di wilayah Cibubur dan juga pengembangan perumahan skala kota yang pembangunannya dilakukan oleh PT. PT. Dwikarya Langgeng Sukses, konsorsium 3 pengembangan yaitu Grup Suryamas Dutamakmur, Grup Duta Putra Mahkota dan Kalindoland.

Selain itu juga PT. Dwigunataman Ristisprima membuat masterplan sebagai penyelarasan perkembangan dalam pembangunan insfrastruktur serta jalur transportasi masal agar terintegrasi dengan area hunian, komersial serta fasilitas umum dan fasilitas sosial. Dengan perkembangan yang semakin pesat pembangunan property maka Harvest City memiliki konsep skala kota yang diprediksi menjadi trensetter perumahan di kawasan Cibubur-Jonggol.

Hasil penelitian pengolahan data menunjukan Model matematik yang membangun model pengukuran masingmasing variabel laten adalah sebagai berikut:

1. Model persamaan pengukuran bauran pemasaran:

$\mathrm{MM} 1=0,83 \mathrm{MM}+\mathrm{e} 1(0,15)$

$\mathrm{MM} 2=0,50 \mathrm{MM}+\mathrm{e} 2(0,46)$

$\mathrm{MM} 3=0,75 \mathrm{MM}+\mathrm{e} 3(0,22)$

MM4 $=0,73 \mathrm{MM}+\mathrm{e} 4(0,22)$

2. Model persamaan pengukuran variabel kepuasan konsumen:

$\mathrm{SC} 1=0,91 \mathrm{SC}+\mathrm{e} 5(0,10)$

$\mathrm{SC} 2=0,83 \mathrm{SC}+\mathrm{e} 6(0,8)$

$\mathrm{SC} 3=0,55 \mathrm{SC}+\mathrm{e} 7(0,56)$

$\mathrm{SC} 4=0,61 \mathrm{SC}+\mathrm{e} 8(0,26)$

3. Model persamaan pengukuran variabel kepercayaan konsumen:

TR1 $=0,62$ TR $1+$ e $12(0,28)$

$\mathrm{TR} 2=0,90 \mathrm{TR} 2+\mathrm{e} 13(0,11)$

TR3 $=0,63$ TR3 + e14 $(0,28)$

4. Model persamaan pengukuran variabel loyalitas konsumen :

$\mathrm{LY} 1=0,71 \mathrm{LY} 1+\mathrm{e} 9(0,32)$

$\mathrm{LY} 2=0,62 \mathrm{LY} 2+\mathrm{e} 10(0,29)$

$\mathrm{LY} 3=0,82 \mathrm{LY} 3+\mathrm{e} 11(0,16)$

Model matematik yang membangun model struktural adalah sebagai berikut: $\mathrm{SC}=0,805 \mathrm{MM}+$ eror $=0,83 \rightarrow \mathrm{R}^{2}=0,17$ $\mathrm{TR}=0,440 \mathrm{MM}+0,364 \mathrm{SC}+$ eror $=0,89 \rightarrow$ $\mathrm{R}^{2}=0,11$

$\mathrm{LY}=0,137 \mathrm{MM}+0,223 \mathrm{SC}+0,519 \mathrm{TR}+$ eror $=0,82 \rightarrow R^{2}=0,18$ 


\section{Pengujian Hipotesis 1: Pengaruh Bauran Pemasaran (MM) Terhadap Kepuasan (SC).}

Ajuan hipotesis kesatu yaitu pengaruh MM terhadap SC pada Perumahan Harvest City oleh nilai koefisien sebesar $\lambda 1=0.805$. Nilai koefisien $\lambda 1=0.805$ memiliki nilai probabilitas sebesar $\mathrm{p}=0.001$ dan nilai critical ratio sebesar $\mathrm{CR}=6.954$. Karena probabilitas lebih kecil dari pada taraf uji penelitian ( $\mathrm{p}<\alpha$ atau $0.001<0.05)$, maka $\mathrm{H} 1 \mathrm{o}$ diterima dan $\mathrm{H} 1 \mathrm{a}$ ditolak yang berarti ada pengaruh MM terhadap SC. hasil pengujian menunjukkan bahwa hipotesis pertama penelitian ini diterima yang berarti bahwa terdapat pengaruh MM terhadap SC.

\section{Pengujian Hipotesis 2: Bauran Pemasaran (MM) Terhadap Kepercayaan (TR). \\ Selanjutnya hipotesis kedua pengaruh bauran pemasaran (MM) terhadap Kepercayaan (TR) pada} Perumahan Harvest City ditunjukkan oleh nilai koefisien sebesar $\lambda 2=0.440$. Nilai koefisien $\lambda 2=0.440$ memiliki nilai probabilitas sebesar $\mathrm{p}=0.031$ dan nilai critical ratio sebesar $\mathrm{CR}=2.162$. Karena probabilitas lebih kecil dari pada taraf uji penelitian $(\mathrm{p}<\alpha$ atau $0.031<0.05)$, maka $\mathrm{H} 2 \mathrm{o}$ diterima dan $\mathrm{H} 2 \mathrm{a}$ ditolak yang berarti pengaruh bauran pemasaran berpengaruh terhadap kepercayaan (TR) adalah signifikan. Signifikansi hasil pengujian menunjukkan bahwa hipotesis kedua penelitian ini diterima yang berarti bahwa terdapat pengaruh MM terhadap TR.

\section{Pengujian Hipotesis 3: Pengaruh Bauran pemasaran (MM) Terhadap loyalitas (LY).}

Untuk hipotesis ketiga pengaruh MM terhadap LY pada Perumahan Harvest City ditunjukkan oleh nilai koefisien sebesar $\beta 3=0.137$. Nilai koefisien $\beta 3=$ 0.137 memiliki nilai probabilitas sebesar $\mathrm{p}=0.499$ dan nilai critical ratio sebesar $\mathrm{CR}=0.676$. Karena probabilitas lebih besar dari pada taraf uji penelitian ( $\mathrm{p}>\alpha$ atau $0.499>0.05$ ), maka H3o ditolak dan H3a diterima yang berarti pengaruh MM terhadap LY adalah tidak signifikan.
Signifikansi hasil pengujian menunjukkan bahwa hipotesis ketiga penelitian ini ditolak yang berarti bahwa tidak terdapat pengaruh MM terhadap LY.

\section{Pengujian Hipotesis 4: Pengaruh Kepuasan (SC) Kepercayaan (TR).}

Yang keempat hipotesis ini adalah pengaruh SC terhadap TR pada Perumahan Harvest City ditunjukkan oleh nilai koefisien sebesar $\beta 4=0.364$. Nilai koefisien $\beta 4=0.364$ memiliki nilai probabilitas sebesar $\mathrm{p}=0.086$ dan nilai critical ratio sebesar $\mathrm{CR}=1.715$. Karena probabilitas lebih tinggi dari pada taraf uji penelitian $(\mathrm{p}>\alpha$ atau $0,086>0.05)$, maka $\mathrm{H} 40$ ditolak dan $\mathrm{H} 4 \mathrm{a}$ diterima yang berarti tidak ada pengaruh SC terhadap TR adalah tidak signifikan. Signifikansi hasil pengujian menunjukkan bahwa hipotesis keempat penelitian ini ditolak yang berarti bahwa tidak terdapat pengaruh SC terhadap TR.

\section{Pengujian Hipotesis 5: Pengaruh Kepuasan (SC) Terhadap loyalitas (LY).}

Sementara hipotesis yang kelima tidak terdapat pengaruh SC terhadap LY pada Perumhan Harvest City ditunjukkan oleh nilai koefisien sebesar $\beta 5=0.223$. Nilai koefisien $\beta 5=0.223$ memiliki nilai probabilitas sebesar $\mathrm{p}=$ 0.287 dan nilai critical ratio sebesar $\mathrm{CR}=$ 1.064. Karena probabilitas lebih tinggi dari besar pada taraf uji penelitian ( $\mathrm{p}>$ $\square$ atau 0,287 > 0.05), maka H3o ditolak dan H3a diterima yang berarti tidak ada pengaruh SC terhadap LY adalah tidak signifikan. Signifikansi hasil pengujian menunjukkan bahwa hipotesis kelima penelitian ini ditolak yang berarti bahwa tidak terdapat pengaruh SC terhadap LY.

\section{Pengujian Hipotesis 6: Pengaruh kepercayaan (TR) Terhadap loyalitas (LY).}

Hasil hipotesis keenam terdapat pengaruh TR terhadap LY pada Perumahan Harvest City ditunjukkan oleh nilai koefisien sebesar $\beta 6=0.519$. Nilai koefisien $\beta 6=0.519$ memiliki nilai probabilitas sebesar $\mathrm{p}=0.012$ dan nilai critical ratio sebesar $\mathrm{CR}=2.513$. Karena 
probabilitas lebih kecil pada taraf uji penelitian ( $\mathrm{p}<\square$ atau $0.012<0.05)$, maka H3o diterima dan H3a ditolak yang berarti pengaruh TR terhadap LY adalah signifikan. Signifikan hasil pengujian menunjukkan bahwa hipotesis keenam penelitian ini diterima yang berarti bahwa terdapat pengaruh TR terhadap LY.

\section{Pembahasan}

Pengaruh Bauran Pemasaran (MM) Terhadap Kepuasan (SC)

Kualitas bauran pemasaran berpengaruh secara positif terhadap kepuasan. Hal ini dapat dibuktikan apabila dilihat dari nilai koefisien 0,805 dan nilai critical ratio (CR) 6.954, serta nilai probabilitas 0,001 . Hal ini dapat diartikan bahwa semakin baik bauran pemasaran maka semakin tinggi pula kepuasan customer terhadap perusahaan.

Hasil penelitian ini sesuai dengan teori Menurut Sumarmi dan Soeprihanto (2010:274) menyatakan bahwa yang mempengaruhi kepuasan konsumen untuk perusahaan adalah kombinasi dari marketing mix yaitu produk, tempat, harga dan promosi. Hasil penelitian ini juga diperkuat oleh penelitian sebelumnya yang dilakukan oleh Ade Letrio Putra (2000) dimana bauran pemasaran berpengaruh signifikan terhadap kepuasan. Temuan yang sama juga terdapat pada hasil penelitian yang dilakukan oleh Andrew A Lumintang (2005).

Dimensi dari bauran pemasaran dapat menciptakan nilai positif bagi kepuasan konsumen. Semakin baik tangibles dan reliability maka akan membuat konsumen semakin puas kepada developer yang mempunyai integritas.

Banyak hal yang dapat dilakukan oleh Harvest City agar bauran pemasaran dapat meningkatkan kepuasan konsumen. Manajemen Harvest City dapat berupaya meningkatkan bauran pemasaran sehingga konsumen merasa diberikan kepuasan dalam pengambilan unit di Harvest City.

\section{Pengaruh Bauran Pemasaran} Terhadap Kepercayaan (TR)

(MM)

Bauran pemasaran berpengaruh secara positif terhadap kepercayaan. Hal ini dapat dibuktikan apabila dilihat dari nilai koefisien 0,440 dan nilai critical ratio (CR) 7,799, probabilitas 0,031. Bauran pemasaran mempunyai pengaruh yang besar dan signifikan terhadap kepercayaan.

Hasil ini sesuai dengan teori oleh Cronin (2000) dimana bauran pemasaran berpengaruh signifikan terhadap kepercayaan. Temuan yang sama juga terdapat pada hasil penelitian yang dilakukan oleh Heru Mulyanto (2013), Erwinsyah Putra, Muhklis Yunus \& Sulaiman (2012) dimana bauran pemasaran berpengaruh signifikan terhadap kepercayaan.

Dimensi dari bauran pemasaran dapat menciptakan nilai positif bagi kepercayaan konsumen. Semakin baik bauran pemasaran, maka akan membuat konsumen semakin percaya kepada perusahaan dalam hal credibility. Dalam penelitian ini bauran pemasaran yang utama adalah product, place, price dan promotion. Indikator tersebut dapat mempengaruhi kepercayaan konsumen utamanya pada dimensi credibility.

\section{Pengaruh Bauran Pemasaran terhadap Loyalitas (LY)}

Bauran pemasaran tidak berpengaruh terhadap loyalitas. Hal ini dapat dibuktikan apabila dilihat dari nilai koefisien 0,137 dan nilai critical ratio (CR) 0,676 serta probabilitas 0,449. Artinya tinggi rendahnya bauran pemasaran tidak akan merubah konsumen menjadi lebih loyal.

Tetapi penelitian ini tidak sejalan dengan teori Menurut Sumarmi dan Soeprihanto (2010:274) dimana loyalitas konsumen itu dipengaruhi oleh kombinasi variabel marketing mix yaitu produk, tempat, harga dan promosi. Tidak adanya pengaruh ini bauran pemasaran terhadap loyalitas terjadi karena bisa dilihat dari produk yang tidak sesuai, harga yang terlalu tinggi, tempat dan akses yang tidak memadai, promosi yang tidak menarik. Tidak adanya pengaruh bauran pemasaran 
terhadap loyalitas membawa konsekwensi bahwa perusahaan memprioritaskan dan meningkatkan bauran pemasaran untuk mencapai tujuan perusahaan.

\section{Pengaruh Kepuasan (SC) terhadap Kepercayaan (TR)}

Kepuasan tidak berpengaruh terhadap loyalitas. Hal ini dapat dibuktikan apabila dilihat dari nilai koefisien 0,364 dan nilai critical ratio (CR) 1,715 serta probabilitas 0,086. Hal ini dapat diartikan bahwa tinggi rendahnya kepuasan tidak akan merubah kepercayaan konsumen. Konsumen yang merasa tidak puas tidak akan berkurang kepercayaannya terhadap perusahaan, sebaliknya konsumen yang merasa puas juga tidak akan meningkatkan kepercayaan pada perusahaan.

Tetapi penelitian ini tidak sejalan dengan teori Zeitahmi dan Bitner (2003:93), dimana faktor kepuasan berpengaruh terhadap kepercayaan. Hasil penelitian ini juga berbeda dengan penelitian sebelumnya dimana kepuasan mempengaruhi kepercayaan, Dewi Pebranadian Putra (2016), Yashinta Asteria Norhermaya, Harry Soesanto, (2009). Tidak adanya pengaruh ini kepuasan terhadap kepercayaan terjadi karena bisa dilihat dari karakter responden, deskripsi variabel, dan argument lainnya. Tidak adanya pengaruh kepuasan terhadap kepercayaan membawa konsekwensi bahwa perusahaan memprioritaskan upaya meningkatkan kepuasan konsumen dalam rangka mendapatkan kepercayaan konsumen.

\section{Pengaruh Kepuasan (SC) terhadap Loyalitas (LY)}

Kepuasan tidak berpengaruh terhadap loyalitas, hal ini dapat dibuktikan apabila dilihat dari nilai koefisien 0,223 dan nilai critical ratio (CR) 1,064serta nilai probabilitas 0,287. Artinya bahwa tingi rendahnya kepuasan tidak akan merubah loyalitas konsumen terhadap perusahaan. Konsumen yang tidak puas tidak akan berkurang loyalitasnya terhadap perusahaan, sebaliknya konsumen yang merasa puas juga tidak akan meningkatkan loyalitas pada perusahaan.

Hasil penelitian ini tidak sejalan dengan teori Tjiptono, (1997), dimana loyalitas pelanggan tercipta dengan adanya rasa puas dari pelanggan yang kemudian terjadi harmonisasi antara perusahaan dengan pelanggan yang pada akhirnya pelanggan kembali membeli ulang produk yang ada yang pada akhirnya dapat membentuk rekomendasi tanpa disadari dari mulut ke mulut yang membawa keuntungan bagi perusahaan atas sikap pelanggan tersebut.

Menurut penelitian yang dilakukan oleh Cerri Shpetim (2012) loyalitas pelanggan dipengaruhi oleh kepuasan pelanggan. Hal ini juga didukung oleh penelitian yang dilakukan oleh Mohammad Muzahid Akbar dan Noorjanah Parvez (2009) menyatakan bahwa kepuasan pelanggan memiliki pengaruh yang signifikan terhadap loyalitas pelanggan.

Penelitian ini juga tidak sejalan dengan penelitian yang dilakukan oleh Miladyah (2012) yang menyatakan bahwa kepuasan berpengaruh signifikan terhadap loyalitas konsumen. Sebagai konsekwensi dari penelitian ini Tidak adanya pengaruh kepuasan terhadap loyalitas, konsumen yang merasa tidak puas maka tidak memberikan loyalitasnya seperti referensi atau rekomendasi untuk pembelian unit di Harvest City.

\section{Pengaruh Kepercayaan (TR) Terhadap Loyalitas (LY)}

Kepercayaan memiliki pengaruh yang besar dan signifikan terhadap loyalitas konsumen. Hal ini dapat dibuktikan apabila dilihat dari nilai koefisien 0,519 dan nilai critical ratio (CR) 2,513 serta probabilitas 0,001. Artinya bahwa tinggi rendahnya kepercayaan konsumen dapat memberikan loyalitas terhadap perusahaan.

Hasil ini sesuai dengan studi sebelumnya yang dilakukan oleh Oliver (1999) dimana kepercayaan berpengaruh signifikan terhadap loyalitas. Temuan yang sama juga terdapat pada hasil 
penelitian yang dilakukan oleh Angga Arianto Pribadi (2010). Hasil penelitian ini juga diperkuat oleh Kristian Hariyono Putro (2015) yang menyatakan bahwa kepercayaan dapat berpengaruh terhadap loyalitas konsumen. Dimesi dari kepercayaan dapat menciptakan nilai positif bagi loyalitas konsumen. Semakin baik integrity dan kompetence maka akan membuat konsumen semakin loyal kepada developer.

\section{KESIMPULAN}

\section{Simpulan}

1. Bauran Pemasaran berpengaruh secara positif terhadap kepuasan konsumen yang dapat diartikan bahwa semakin baik bauran pemasaran maka semakin tinggi pula kepuasan customer terhadap perusahaan. Bauran pemasaran dapat menciptakan nilai positif bagi kepuasan konsumen.

2. Bauran pemasaran berpengaruh secara positif terhadap kepercayaan konsumen bahwa semakin baik bauran pemasaran maka semakin tinggi pula kepercayaan konsumen terhadap perumahan Harvest City.

3. Bauran Pemasaran tidak berpengaruh terhadap loyalitas konsumen yang dapat diartikan bahwa baik buruknya bauran pemasaran tidak merubah pada loyalitas konsumen di Perumahan Harvest City.

4. Kepuasan tidak berpengaruh terhadap kepercayaan yang dapat diartikan bahwa tinggi rendahnya kepuasan tidak akan merubah kepercayaan konsumen. Konsumen yang merasa tidak puas tidak akan berkurang kepercayaannya terhadap perusahaan, sebaliknya konsumen yang merasa puas juga tidak akan meningkatkan kepercayaan pada perusahaan.

5. Kepuasan tidak berpengaruh terhadap loyalitas, Artinya bahwa tingi rendahnya kepuasan tidak akan merubah loyalitas konsumen terhadap perusahaan. Konsumen yang tidak puas tidak akan berkurang loyalitasnya terhadap perusahaan, sebaliknya konsumen yang merasa puas juga tidak akan meningkatkan loyalitas pada perusahaan.

6. Kepercayaan memiliki pengaruh positif terhadap loyalitas konsumen yang dapat diartikan bahwa bahwa tinggi rendahnya kepercayaan konsumen dapat memberikan loyalitas terhadap perusahaan.

\section{Saran}

1. Perusahaan perlu menelaah kembali sistem manajemen yang telah dijalankan selama ini. Alasan alasan yang diungkapkan oleh konsumen dapat dijadikan suatu masukan yang cukup konstruktif bagi perusahaan guna mengetahui kesetiaan konsumen lebih baik.

2. Perusahaan dan peneliti lain diharapkan mengkaji ulang penelitian ini khususnya berkaitan dengan kepuasan dalam mempengaruhi loyalitas serta kepercayaan dalam mempengaruhi loyalitas.

3. Perusahaan dan peneliti lain diharapkan melakukan penelitian lanjutan dengan pengukuran dan variable yang lebih lengkap, obyek penelitian yang lebih luas dan memiliki karakteristik yang berbeda serta. permasalahan yang lebih spesifik sehingga diperoleh temuan yang dapat digeneralisasi guna menambah khasanah keilmuan khususnya di bidang manajemen pemasaran.

\section{DAFTAR PUSTAKA}

Cory Caroline R.M, Edy Yulianto, Sunarti. (2016). Pengaruh Bauran Pemasaran Terhadap Kepuasan Konsumen (Survei Kepada Konsumen Kendaraan Merek Toyota Di Univeritas Brawijaya Malang). Jurnal Administrasi Bisnis. Vo.30, No 1.

Griffin, Jill. (2002). Costumer Loyalty. Jakarta: Erlangga

Hadiyati, Ernani. (2010). Analisis Kualitas Pelayanan dan Pengarunya terhadap Loyalitas 
Pelanggan (Studi Kasus pada PT. Pos Indonesia (Persero) Kantor Pos Lawang). Jurnal Manajemen. Vol. 2, Nomor 2, Juli - Desember 2010. Universitas Gajayana. Malang.

Hurriyati, Ratih. (2005). Bauran Pemasaran Dan Loyalitas Konsumen, Penerbit Cv. Alfabeta, Bandung.

Lovelock, Christoper. 2004). Service Marketing People, Technology, Strategy, Prentice Hall, United States of America.

Lumintang, Andrew A. (2006). Marketing Mix Pengaruhnya Terhadap Loyalitas Konsumen Sabun Mandi Lifebuoy Di Kota Manado. Jurnal Penelitian UNSRAT.

Kotler, Philip. (2009). Manajemen Pemasaran. Terjemahan Penerbit Erlangga, Northwestern.

Lupiyoadi Rambat, Hamdani A. (2006). Manajemen Pemasaran jasa. Jakarta: Salemba Empat.

MK. Wardani, D Fajri. (2016). Citra Merek Dan Kepuasaan Konsumen Pengaruhnya Terhadap Loyalitas Konsumen Pt. Kabel Metal Indonesia Di Jakarta. Jurnal Manajemen Kewirausahaan. Vol 13 No. 2. e-ISSN 2654-9247. p_ISSN 18581048.

Mulyanto, H., Rasipan, Meli Andriyani, 2018, Reputasi dalam Mendorong Kepercayaan dan Minat Beli Konsumen Produk Makanan UMKM di Cileungsi, Jurnal Manajemen Kewirausahaan. Vol 15 No. 2. e-ISSN 2654-9247. p_ISSN 18581048 , DOI: http://dx.doi.org/10.33370/jmk.v $\underline{15 i 2.270}$

Norhermaya dan Soesanto, (2009). Analisis Pengaruh Kepuasan Pelanggan Terhadap Kepercayaan Dan Loyalitas Pelanggan Untuk Meningkatkan Minat Beli Ulang Studi Pada Online Store Lazada.Co.Id.

https://ejournal3.undip.ac.id/inde x.php/djom/article/view/14952
Putra, Ade Letrio, (2006). Pengaruh Bauran Pemasaran Jasa Terhadap Kepuasan dan Loyalitas Nasabah PT. Pegadaian (Persero) Cabang Mengwi, Badung, Bali. Jurnal Penelitian Universitas Udayana.

Putra, Dewi Pebranadian, (2016). Pengaruh kepuasan dan kepercayaan terhadap loyalitas pelanggan toko Online. Penelitian Universitas Islam Negeri Jakarta.

Putra dkk, (2012). Pengaruh Bauran Pemasaran Jasa Terhadap Kepercayaan Merek (Brand Trust) Dan Dampaknya Pada Keputusan Mahasiswa Memilih Kuliah Di Politeknik Aceh. http://journal.feb. unmul.ac.id/index.php/KINERJA/ article/view/4628

Qurroty. (2012). Pengaruh Kepuasan Pelanggan Terhadap Kepercayaan, Loyalitas Dan Pembelian Ulang Pada Pelanggan Kosmetik Cantik Di Surabaya. Sekolah Tinggi Ilmu Ekonomi Perbanas Surabaya.

Satyadharma, (2008). Pengaruh kepuasan pelanggan terhadap kepercayaan merek, loyalitas merek, dan ekuitas merek Mi Instan Indomie di Surabaya. Studi Kasus di Magister Manajemen Fakultas Bisnis dan Ekonomika Universitas Surabaya.

Sumarwan, U., (2003). Perilaku Konsumen: Teori dan Penerapannya dalam Pemasaran. Jakarta: Ghalia Indonesia.

Sunarto, Andi. (2009), Seluk Beluk ECommerce, Gerai Ilmu. Yogyakarta.

Tjiptono, Fandy. (2008). Strategi pemasaran. Penerbit Andi, Yogyakarta.

Tjiptono, F dan Chandra,G. (2011). Service, Quality \& Satisfaction. Penerbit Andi, Yogyakarta.

Umar, Husein. (2003). Riset Pemasaran dan Prilaku Konsumen. PT Gramedia Pustaka Utama, Jakarta. 